\title{
Pelayanan Sosial dan Keagamaan Dengan Menggunakan Media Audio Visual Dalam Meningkatkan WPKNS ABH di Lembaga Permasyarakatan Kelas II A Curup
}

\author{
Fadila \\ Institut Agama Islam Negeri (IAIN) Curup \\ unifadila@yahoo.co.id \\ Eka Yanuarti \\ Institut Agama Islam Negeri (IAIN) Curup \\ Ekayanuarti14@gmail.com
}

\begin{abstract}
The article is the result of actions taken in research to improve the WPKNS ABH. The method used in this paper is descriptive analysis, by presenting the results of the study and analyzing the results obtained in the study. The WPKNS ABH is giving donations to Curup Class II Lapas. By coordinating with the Lapas and Stakeholders, in the form of Islamic material, general education material, soft skills, national knowledge and insights, providing counseling services and holding an Islamic Competition. The results of the study and actions showed the insight, knowledge, skills, values and attitudes of the $\mathrm{ABH}$ in Class II A Curup Prison, before and after the action: $\mathrm{ABH}$ insights increased by $52.5 \%$ from the total score before the action amounted to 28 (35\%) increased to a total of $75(87.5 \%)$ after the action. ABH's knowledge increased by $41.25 \%$, the overall total score before carrying out the actions amounted to $62(38.75 \%)$ increased to $128(80 \%)$ after the action. ABH's skills experienced an increase of $52.5 \%$ from a total score of $28(35 \%)$ before the action became $75(87.5 \%)$ after the action was taken. The aspect of $\mathrm{ABH}$ value increased by $58.75 \%$ from the initial total score of $26(32.5 \%)$ to $73(91.25 \%)$ after the action was taken. The attitude aspect of $\mathrm{ABH}$ increased by $43.75 \%$ from the total score of $35(43.75 \%)$ to $75(87.5 \%)$ after the action was taken.
\end{abstract} Keywords: WPKNS, Lapas II A Curup, Guidance and Counseling

\section{Abstrak}

Artikel merupakan hasil dari tindakan yang dilakukan dalam penelitian dalam meningkatkan WPKNS ABH. Metode yang digunakan dalam tulisan ini adalah deskriptif analisis, dengan 
mengemukakan hasil dari penelitian serta menganalisa hasil yang didapat dalam penelitian. WPKNS ABH adalah pemberian bantuan sumbangan kepada Lapas Kelas II A Curup. Dengan melakukan koordinasi bersama pihak Lapas dan Stakeholder, berupa materi keislaman, materi pendidikan umum, keterampilan softskill, pengetahuan dan wawasan kebangsaan, memberikan layanan konseling serta mengadakan Perlombaan Keislaman. Hasil penelitian dan tindakan menunjukkan wawasan, pengetahuan, keterampilan, nilai dan sikap ABH di Lapas Kelas II A Curup, sebelum dan sesudah tindakan yaitu: wawasan $\mathrm{ABH}$ mengalami peningkatan sebesar $52,5 \%$ dari skor total sebelum tindakan berjumlah $28(35 \%)$ meningkat menjadi total keseluruhan 75 $(87,5 \%)$ setelah tindakan. Pengetahuan ABH mengalami peningkatan sebesar $41,25 \%$, skor total keseluruhan sebelum dilaksanakan tindakan berjumlah $62(38,75 \%)$ meningkat menjadi $128(80 \%)$ setelah tindakan. Keterampilan $\mathrm{ABH}$ mengalami peningkat sebesar $52,5 \%$ dari skor total berjumlah 28 (35\%) sebelum tindakan menjadi $75(87,5 \%)$ setelah dilaksanakan tindakan. Aspek nilai ABH mengalami peningkatan sebesar 58,75\% dari skor total awal berjumlah $26(32,5 \%)$ menjadi 73 (91,25\%) setelah dilaksanakan tindakan. Aspek sikap $\mathrm{ABH}$ mengalami peningkatan sebesar 43,75\% dari skor total berjumlah $35(43,75 \%)$ menjadi 75 $(87,5 \%)$ setelah dilaksanakan tindakan.

Kata Kunci: WPKNS, Lapas II A Curup, Bimbingan dan Konseling

\section{Pendahuluan}

Menurut Romli Atmasasmita dalam Wagiati Soetodjo, ada beberapa faktor yang memungkinkan anak anak untuk melakukan kenakalan dan kegiatan kriminal yaitu motivasi intrinsik dan ekstrinsik. Faktor dari dalam seperti kecerdasan, usia, kelamin dan posisi anak dalam keluarga, sementara faktor ekstrinsik seperti kondisi rumah tangga, pendidikan dan kondisi keluarga, pola interaksi anak dan pemanfaatan media massa. ${ }^{1}$ Faktor ini yang dapat membuat mereka menjadi ABH. Hal ini berdasarkan Undang-Undang Sistem Peradilan Pidana Anak No. 11 Tahun 2012Pasal 1 ayat (2) UU, ABH adalah Anak yang bermasalah dengan hukum, anak yang menjadi korban dari pelanggaran hukum atau tindak pidana, dan anak yang menjadi saksi dari pelanggaran hukum atau tindak pidana.

Pendapat di atas didukung oleh penelitian yang dilakukan oleh Meilyana Megasari dan Nyoman Dewa Rai Asmara Putra, yang membuat kesimpulan dalam penelitiannya bahwa Anak yang diduga telah melakukan tindak pidana 
pada dasarnya dapat dipengaruhi oleh faktor dari dalam dan luar diri anak seperti lingkungan pergaulan, pendidikan, dan lingkungan sekitar serta minimnya pengawasan terhadap anak oleh orang tuanya. ${ }^{2}$ Selain itu penelitian yang dilakukan oleh Febry Hizba Ahshaina Suharto,dkk, kesimpulan yang dapat diambil dari berbagai persoalan dan permaslahan yang timbul di masyarakat seperti tidak adanya komunikasi dan interaksi yang baik dalam keluarga. Faktor lingkungan, seperti dalam individu, keluarga, dan masyarakat yang sekarang terjadi kemajuan teknologi informasi pengetahuan dan globalisasi dewasa ini mempengaruhi tatanan nilai, akhlak, etika dan norma yang berlaku di keluarga dan lebih luas lagi masyarakat. Hal ini menyebabakan terjadinya berbagai permasalahan sosial pada anak diantaranya; penyimpangan perilaku baik pada anak maupun pada orang dewasa, seperti tindak pelecehan seksual, kekerasan, tawuran, pencurian, dan lain-lain yangmenyebabkan anak berhadapan dengan hukum $(\mathrm{ABH})^{3}$

ABH tersebut pada umumnya di tempatkan di Lapas. Di dalam Lapas, maka peran orang tua dan keluargapun tidak dapat berfungsi lagi sebagaimana mestinya, namun jangan begitu khawatir, di dalam Lapas ABH tidak dibiarkan begitu saja, mereka juga berhak mendaptakan pendampingan. SK Menteri Kehakiman Tahun 1990, No.M.02.PK.04.10 menjelaskan tentang Pola Pembinaan Narapidana, sudah diatur dengan dua pola pembinaan, yaitu: pertama, pembinaan secara umum teridiri dari pembinaan kepribadian dan pembinaan kemandirian. Pembinaan kepribadian meliputi: Pembinaan kesadaran berbangsa dan bernegara, Pembinaan kesadaran beragama/ketaqwaan kepada Tuhan Yang Maha Esa. Pembinaan kemandirian diberikan melalui program mendukung usaha-usaha mandiri narapidana seperti memberikan keterampilan yang sesuai dengan masing-masing bakatnya dan bermanfaat di masa depan. Kedua, Pembinaan secara khusus, meliputi: Berhasil memantapkan kembali harga diri dan kepercayaan dirinya sehingga mereka merasa optimis akan masa depannya. Memperoleh pengetahuan. Berhasil menjadi manusia patuh hukum.

Pembelajaran dan pembinaan dapat lebih menarik dan cepat mencapai tujuan pembelajaran, jika pembelajaran didukung dengan penggunaan media audio visual. Menurut Rinanto "media audio visual merupakan gabungan gambar dan suara, yang mampu membawa penonton terhanyut dalam pemikiran dan perasaan akan hal yang ditonton". Media audio visual terdiri dari software yaitu bahan-bahan informasi yang terdapat dalam sound slide, $C D$, DVD, televisi, film, dan hardware yaitu segenap peralatan teknis yang memungkinkan software bisa dinikmati contohnya tape, proyektor, slide, dan

\section{${ }^{2}$ Ibid}

${ }^{3}$ Febry Hizba Ahshaina Suharto, d. ,. (n.d.). Interaksi didalam Keluarga dengan Anak Berhadapan dengan Hukum di Panti Sosial Masurdi Putra Bambu Apus Jakarta. Share Social Work Jurnal, Volume: 5 Nomor: 1, Hal. 35-45. 
proyektor film.4 Penggunaan media Audio Visual membawa berbagai manfaat seperti pada penelitian yang dilakukan oleh Jatmiko Sidi dan Mukminan pada tahun 2016 dengan hasil penelitian menunjukkan bahwa penggunaan media audiovisual dalam pembelajaran IPS dapat meningkatkan hasil belajar siswa.5

Namun, observasi awal di Lapas Kelas II A Curup Kabupaten Rejang Lebong masih terdapat berbagai masalah yang ditemukan, yaitu: ${ }^{6}$

1. Kabupaten Rejang Lebong memiliki Lembaga pemasyarakatan yang mengalami kelebihan kapasitas dan warga binaannya bercampur antara orang dewasa dan anak-anak. Jumlah warga binaan dewasa sebanyak 678 orang dan anak-anak ada 23 orang.

2. Lembaga pemasyarakatan Kabupaten Rejang Lebong Petugas Pembina di lembaga pemasyarakatan tidak sebanding dengan warga binaan, yaitu berjumlah 75 petugas

3. Anak-anak berhadapan dengan hukum (ABH) memiliki wawasan, pengetahuan, keterampilan, nilai dan sikap yang masih rendah.

4. Media dan fasilitas pembelajaran seperti bahan ajar yang kurang, serta pendidik/tutor yang kurang profesional, serta media pembelajaran yang masih sederhana, seperti hanya papan tulis dan spidol.

\section{Pembahasan dan Hasil}

\section{A. Media Audio Visual}

Media audio visual yaitu media yang mempunyai unsur suara dan gambar. Media ini dibagi menjadi audio visual diam seperti film bingkai suara (soundslid) dan film rangkaian suara, audio visual gerak, seperti film suara dan film kasett. Media audio visual adalah seperangkat alat yang dapat memproyeksikan gambar bergerak dan bersuara. Paduan antara gambar dan suara membentuk karakter sama dengan objek aslinya.7
a. Manfaat penggunaan media audio visual adalah:
b. Membantu memberikan konsep pertama atau kesan yang benar
c. Mendorong minat
d. Meningkatkan pengertian yang lebih baik
e. Melengkapi sumber belajar yang lain
f. Menambah variasi metode mengajar
g. Menghemat waktu
h. Meningkatkan keingintahuan intelektual

\footnotetext{
${ }^{4}$ Rinanto, A. (1982). Peranan Media Audiovisual dalam Pendidikan. Yogyakarta: Kanisius. 5Jatmiko Sidi, Mukminan. (Juni 2016, ). Penggunaan Media Audiovisual untuk Meningkatkan Hasil belajar IPS di SMP. Jurnal Ilmu-Imu Sosia, Volume 15. No.1, Hal. 53-72.

${ }^{6}$ Observasi, April 2018.

${ }^{7}$ Imam Taufik, Penerapan Media Audio Visual Dalam Meningkatkan Presentasi Belajar Bahasa Arab, (Yogyakarta : UIN Sunan Kali Jaga, 2013), hal.13.
} 
i. Cenderung mengurangi ucapan dan pengulangan kata yang tidak perlu

j. Membuat ingatan terhadap pelajaran lebih lama

k. Dapat memberikan konsep baru dari sesuatu diluar pengalaman biasa ${ }^{8}$

Dalam pengaplikasian media audio visual ada hal-hal yang harus dipersiapkan misalnya; guru harus tau cara pengoprasian media tersebut, guru harus terlebih dahulu tahu konten alat bantu yang akan digunakan, dan yang pasti harus sesuai dengan indikator pencapaian yang akan dicapai. Berikut akan dijelaskan saran-saran untuk menggunakan media audio visual dalam pembelajaran agar dapat berfungsi secara optimal:

a. Bahan yang disajikan harus mengarah langsung pada masalah yang dibicarakan oleh kelompok, dalam artian harus terarah.

b. Bahan seyogianya hanya disajikan pada waktu yang tepat sehingga tidak menyebabkan terputusnya kelangsungan berpikir.

c. Pimpinan sebaiknya mengetahui bagaimana menjalankan alat bantu.

d. Alat bantu sebaiknya mengajarkan sesuatu, tidak sekedar menayangkan sesuatu.

e. Partisipasi pelajar sangat diharapkan dalam situasi ketika alat bantu audio visual digunakan.

f. Rencana mutlak diperlukan untuk membuat bahan yang disajikan dengan alat bantu lebih efektif.

g. Beberapa alat bantu sebaiknya digunakan.

h. Alat bantu audio visual sebaiknya digunakan secara hati-hati dan disimpan dengan baik $^{9}$

\section{B. Wawasan, Pengatahuan, Keterampilan dan Sikap (WPKNS)}

\section{Wawasan}

Wawasan berasal dari kata dasar wawas. Wawasan adalah sebuah homonim karena arti-artinya memiliki ejaan dan pelafalan yang sama tetapi maknanya berbeda. Wawasan memiliki arti dalam kelas nomina atau kata benda sehingga wawasan dapat menyatakan nama dari seseorang, tempat, atau semua benda dan segala yang dibendakan. ${ }^{10}$

Wawasan adalah pokok kata dari wawas, secara harfiah berarti pandangan/ teropong. Sampai saat ini belum ada arti baku dari wawasan, namun hal ini pada umumnya diartikan sebagai pandangan / teropong multi dimensi seseorang dalam melihat dan menjabarkan keberadaan suatu bidang tertentu

\footnotetext{
${ }^{8}$ Nana Sudjana, Media Pengajaran (Surabaya:Pustaka Dua, 1978), h. 192

${ }^{9}$ Suprijanto, Pendidikan Orang Dewasa (Jakarta: Bumi Aksara, 2005), h. 175

10 Staf MRPK, Arti Kata Wawasan Makna Pengertian Dan Definisi Dari Wawasan,ddmrpk@gmail.com,15 November 2018
} 
secara utuh. Seseorang mempunyai wawasan luas jika dia mempunyai pengetahuan. ${ }^{11}$

Cara memperluas wawasan dapat juga dilakukan dengan cara antara lain yaitu:

a. Rajin membaca

Membaca sangatlah penting dalam memperluas wawasan. Dengan rajin membaca banyak pengetahuan yang bisa didapat selain itu membaca juga bisa meningkatkan pemahaman seseorang. Membaca tidak harus dengan buku non fiksi, membaca buku fiksi juga sangat berguna. Buku merupakan jendela dunia, dengan membaca buku kita bisa menjadi tahu informasi tentang dunia luar yang belum kita ketahui sebelumnya. Selain membaca buku membaca Koran atau surat kabar juga sangat dianjurkan. Dengan membaca Koran kita bisa mengetahui berita-berita terbaru yang aktual baik di dalam negeri maupun luar negeri.

b. Sering berdiskusi

Diskusi merupakan kegiatan bertukar pendapat mengenai sebuah persoalan atau permasalahan. Dengan berdiskusi biasanya terdapat perbedaan pendapat-pendapat mengenai suatu hal. Dalam berpendapat biasanya dilandaskan pengetahuan yang faktual. Dengan berdiskusi kita bisa mendapat pengetahuan baru dari pendapat orang lain yang berbeda tersebut. Dengan sering berdiskusi kita bisa mendapat wawasan baru, selain itu dengan berdiskusi kita bisa meningkatkan analisis dan daya berfikir kita dalam mengungkapkan suatu pendapat atau argument.

c. Berorganisasi

Menurut James D. Mooney, organisaiasi merupakan suatu bentuk pada tiap-tiap perserikatan manusia untuk dapat mencapai tujuan tertentu. Sedangkan menurut menurut Max Weber, organisasi merupakan suatu kerangka hubungan yang terstruktur yang didalamnya itu terdapat wewenang, serta tanggung jawab dan juga pembagian kerja menjalankan sesuatu fungsi tertentu.Salah satu manfaat organisasi ialah menambah wawasan dan pengetahuan, dengan berorganisasi kita banyak menjalin kerja sama dan interaksi sosial dengan anggota organisasi yang lain. Dengan hubungan sosial tersebut banyak hal yang dapat diperoleh dari orang lain yang belum kita ketahui sebelumnya.

d. Manfaatkan media elektronik dan internet dengan baik dan benar

Media elektronik seperti TV sangat berguna dalam menambah wawasan kita,banyak hal yang dapat kita tonton dalm siaran televise, tonton lah sebuah berita atau lainnya yang bermanfaat.Selain TV internet juga memiliki banyak

${ }^{11} \mathrm{http}: / /$ kerajaan-semut.blogspot.com/2010/04/tinjauan-dan-pengertian-pengetahuandan.html di akses tanggal 25 November 2018 
manfaat yang dapat diperoleh, kita bisa mencari materi pelajaran dan informasi apapun dengan mudah dan cepat. TV dan internet memiliki manfaat dalam menambah pengetahuan dan wawasan kita, asalkan kita bisa menggunakannya dengan baik dan benar. ${ }^{12}$

\section{Pengetahuan}

Pengetahuan adalah kumpulan informasi yang didapat dari pengalaman atau sejak lahir yang menjadikan seseorang itu tahu akan sesuatu. Proses kenal, sadar insaf, mengerti dan pandai. ${ }^{13}$

Pengetahuan (knowledge) adalah "hasil tahu dari manusia yang sekedar menjawab pertanyaan "What" misalnya apa air, apa manusia, apa alam, dan sebagainya". Pengetahuan hanya dapat menjawab pertanyaan sesuatu itu. Pengetahuan pada dasarnya terdiri dari sejumlah fakta dan teori yang memungkinkan seseorang untuk dapat memecahkan masalah yang dihadapinya.Pengetahuan sebagai alat jaminan yang sangat penting untuk terbentuknya tindakan seseorang dari pengalaman dan penelitian terbukti bahwa perilaku didasarkan atas pengetahuan akan lebih langgeng dibandingkan dengan tanpa didasari pengetahuan. Pengetahuan merupakan dasar untuk terbentuknya tindakan seseorang. ${ }^{14}$

Pengetahuan yang dimiliki seseorang dipengaruhi oleh faktor-faktor sebagai berikut :

\section{a. Pendidikan}

Tingkat pendidikan seseorang akan berpengaruh dalam memberi respon yang datang dari luar. Orang yang berpendidikan akan berfikir sejauh mana keuntungan yang akan mungkin mereka peroleh dari gagasan tersebut.

b. Paparan Media Massa

Melalui berbagai media baik cetak maupun elektronika berbagai informasi dapat diterima oleh masyarakat, sehingga seseorang yang lebih sering terpapan media masa (televisi, radio, majalah, pamflet) akan memperoleh informasi yang lebih hanya dibandingkan dengan orang yang tidak pernah terpapar informasi media masa.

c. Ekonomi

12 Nurul Khairunissa, Wawasan dan Pengetabuan, Nurul Khairunissa@yahoo.com, tanggal 25 November 2018

${ }^{13}$ Fauziyah Indahyani, Studi Deskriptif Kuantitatif Pengetabuan Guru Sekolab Dasar Tentang Bullying di Kecamatan Sokaraja Kabupaten Banyumas Skripsi, (Fak. Psikologi UMP, 2015), h. 9-10

${ }^{14}$ Fitria Rahmawati, Hubungan Pengetahuan Ibu, Pola Pemberian Makan, dan Pendapatan Keluarga terhadap Status Giri Balita di Desa Pajerukan Kecamatan Kalibagor, Skripsi, (Fak. Ilmu Kesehatan UMP, 2016), h. 10 
Dalam memenuhi kebutuhan primer maupun sekunder, keluarga dengan status ekonomi baik lebih mudah tercukupi dibandingkan keluarga dengan status ekonomi rendah. Hal ini akan mempengaruhi kebutuhan akan informasi yang termasuk kebutuhan sekunder.

d. Hubungan Sosial

Manusia adalah makhluk sosial, dimana dalam kehidupan saling berinteraksi antara satu dengan yang lain. Individu yang dapat berinteraksi secara batinnya akan lebih terpapar informasi. Sementara faktor hubungan sosial juga mempengaruhi kemampuan individu sebagai komunikasi untuk menerima pesan menurut model komunikasi media.

e. Pengalaman

Pengalaman seorang individu tentang berbagai hal bisa diperoleh dan lingkungan kehidupan dalam proses perkembangannya. ${ }^{15}$

\section{Keterampilan}

Kata keterampilan sama artinya dengan kata kecekatan. Terampil atau cekatan adalah kepandaian melakukan sesuatu dengan cepat dan benar. Seseorang yang dapat melakukan sesuatu dengan cepat tetapi salah tidak dapat dikatakan terampil. Demikian pula apabila seseorang dapat melakukan sesuatu dengan benar tetapi lambat, juga tidak dapat dikatakan terampil. ${ }^{16}$

\section{Nilai}

Nilai adalah esensi yang melekat pada sesuatu yang sangat berarti bagi kehidupan manusia, khususnya mengenai kebaikan dan tindak kebaikan suatu hal, Nilai artinya sifat-sifat atau hal-hal yang penting atau berguna bagi kemanusiaan. Nilai adalah sesuatu yang bersifat abstrak, ideal, nilai bukan benda konkrit, bukan fakta, tidak hanya persoalan benar dan salah yang menuntut pembuktian empirik, melainkan sosial penghayatan yang dikehendaki, disenangi, dan tidak disenangi. ${ }^{17}$

\section{Sikap}

Sikap adalah pernyataan evaluatif terhadap objek, orang atau peristiwa. Hal ini mencerminkan perasaan seseorang terhadap sesuatu. Sikap mungkin dihasilkan dari perilaku tetapi sikap tidak sama dengan perilaku. ${ }^{18}$ Sikap adalah

${ }^{15}$ Ibid,. h. 12-13

${ }^{16}$ Khiyarul Anam, Meningkatkan Ketrampilan Membaca Nyaring Me;a;ui Media Pias-pias kata pada Siswa Kelas I di MI Matholibul Huda Ruwit Wedung Demak Tabun Pelajaran 2014-2015,Skripsi, (Fak, Ilmu Tarbiyah dan Keguruan, IAIN Walisongo, 2014), h. 7

${ }^{17}$ Fitriani, I. (2014). Nilai-Nilai Pendidikan Islam Dalam Novel "Bumi Cinta" Karya Habiburrabman El-Sbirazy (Doctoral dissertation, UIN Sunan Ampel Surabaya).

${ }^{18}$ Aro, S., \& Sanur, Y. T. (2013). Sikap Pemuda Terhadap Budaya Daerah Jatilan Di Desa Rejomulyo Lampung Selatan. 
tingkah laku atau gerakan-gerakan yang tampak dan ditampilkan dalam interaksinya dengan lingkungan sosial. Interaksi tersebut terdapat proses saling merespon, saling mempengaruhi serta saling menyesuiakan diri dengan lingkungan sosial. ${ }^{19}$

\section{Anak Berhadapan Dengan Hukum (ABH)}

Dalam Hukum Internasional, anak yang berhadapan dengan hukum atau 'children in conflict with the law' adalah seseorang yang berusia di bawah 18 tahun yang berhadapan dengan sistem peradilan pidana dikarenakan yang bersangkutan disangka atau dituduh melakukan tindak pidana. Persinggungan anak dengan sistem peradilan pidana menjadi titik permulaan anak berhadapan dengan hukum. Istilah sistem peradilan pidana menggambarkan suatu proses hukum yang diterapkan pada seseorang yang melakukan tindak pidana atau melanggar kesesuaian hukum pidana. Dengan demikian istilah sistem peradilan pidana anak dipergunakan untuk menggambarkan sistem peradilan pidana yang dikonstruksikan pada anak.

Menurut Undang-Undang No. 11 Tahun 2012 tentang Sistem Peradilan Pidana Anak, yang dimaksud dengan anak yang berhadapan dengan hukum dibagi menjadi 3 (tiga) golongan, yaitu anak yang berkonflik dengan hukum; anak yang menjadi korban tindak pidana; dan anak yang menjadi saksi tindak pidana. Yang dimaksud dengan Anak yang Berkonflik dengan hukum adalah anak yang telah berumur 12 tahun namun belum berumur 18 tahun yang diduga melakukan tindak pidana. ${ }^{20}$

Penanganan terhadap anak yang berkonflik dengan hukum adalah merupakan tanggung jawab dan kewajiban bersama antara masyarakat dan pemerintah, seperti yang dijelaskan dalam pasal 64 UU Perlindungan Anak No 23 tahun 2002, yaitu:

1. Perlindungan khusus bagi anak yang berhadapan dengan hukum, meliputi anak berkonflik dan anak korban tindak pidana adalah merupakan kewajiban dan tanggung jawab pemerintah dan masyarakat.

2. Perlindungan khusus bagi anak yang berhadapan dengan hukum dilaksanakan melalui; perlakuan atas anak secara manusiawi sesuai dengan martabat dan hak-hak anak, penyediaan petugas pendamping khusus anak sejak dini, penyediaan sarana dan prasarana khusus, penjatuhan sanksi yang tepat untuk kepentingan terbaik anak, pemantauan dan pencatatan secara kontinyu terhadap perkembangan anak, pemberian jaminan untuk berhubungan dengan orang tua atau keliarga, perlindungan dari pemberitaan oleh media dan menghindar dari labelisasi.

\footnotetext{
${ }^{19}$ Rendi Ardiyan, “Pengertian Sikap”, Rendi_Ar@yahoo.com, tanggal 25 November 2018

${ }^{20}$ Kurniawan Rasmen, Anak Yang Berbadapan dengan Hukum diakses pukul 15.00 WIB 15 Oktober 2018
} 
3. Perlindungan khusus bagi anak yang menjadi korban tindak pidana dilaksanakan melalui: upaya rehabilitasi baik dalam lembaga maupun diluar lembaga, upaya perlindungan dari pemberitaan identitas melalui media massa dan untuk menghindari labelisasi, pemberian jaminan keselamatan bagi sanksi korban ahli baik fisik mental maupun sosial, pemberian aksesibilitas untuk mendapatkan informasi mengenai perkembangan perkara. ${ }^{21}$

Penelitian ini menggunakan model Penelitian Participatory Action Research, PAR merupakan salah satu model penelitian yang mencari sesuatu untuk menghubungkan proses penelitian ke dalam proses perubahan sosial. Perubahan sosial yang dimaksud adalah bagaimana dalam proses pemberdayaan dapat mewujudkan tiga tolak ukur, yakni adanya komitmen bersama dengan masyarakat, adanya local leader dalam masyarakat dan adanya institusi baru dalam masyarakat yang dibangun berdasarkan kebutuhan. Penelitian ini membawa proses penelitian dalam lingkaran kepentingan orang dan menemukan solusi praktis bagi masalah bersama dan isu-isu yang memerlukan aksi dan refleksi bersama, dan memberikan kontribusi bagi teori praktis. ${ }^{22}$

Secara umum urutan metodologi kerja PAR, ketiga variabel tersebut dirumuskan sebagai berikut: ${ }^{23}$

1. Research (penelitian), tahap ini adalah merupakan tahapan penelitian, tentang permasalahan-permasalahan yang dihadapi oleh $\mathrm{ABH}$, permasalahan tersebut dipaahami sedemikian mendalam dan mendetail sehingga masalah tersebut dapat diketahuo dengan jelas sebab dan akibatnya.

2. Action (Aksi), setelah mengetahui masalah-masalah tersebut secara mendalam dan mendetail, barulah masuk langkah kedua yaitu pencarian alternatif jalan keluar untuk memecahkan masalah tersebut, yang kemudian diterjemahkan ke dalam beberapa item program kerja yang akan dilaksanakan.

3. Participatory, kedua item di atas dilaksanakan secara partisipatoris, artinya dengan melibatkan seluruh komponen masyarakat dalam melakukan identifikasi masalah serta tehnik pemecahan masalahnya dilakukan bersamasama

Pendekatan penelitian yang digunakan adalah PAR (Partisipation Action Research), maka setelah mengetahui berbagai permasalahan secara mendalam, maka langkah selanjutnya yaitu pencarian alternatif jalan keluar untuk memecahkan masalah tersebut, yang kemudian diterjemahkan kedalam beberapa item program kerja yang dilaksanakan.

\footnotetext{
${ }^{21}$ M. Nasir Djamil, Anak Bukan Untuk di Hukum, ... ., h. 48

22 Agus Afandi, dkk. Modul Participatory Action research (PAR). Surabaya. LPPM. 2013. Hal.55

${ }^{23}$ Burdadi, Kompilasi Program Pengabdian Kepada Masyarakat Bidang Pemberdayaan Komunitas Marjinal (PKM), Direktorat Perguruan Tinggi Islam, Kementrian Agama, 2013. h. 160.
} 


\section{Pelayanan Sosial dan Keagamaan Terhadap Anak Berhadapan Dengan Hukum (ABH) di Lembaga Permasyarakatan Kelas II A Curup Kabupaten Rejang Lebong}

\section{Pembinaan Terhadap ABH Dengan Pola Pesantren}

Pembinaan terhadap anak berhadapan dengan hukum digunakan pola pembinaan pesantren dengan model pembelajaran terpadu, dengan memberikan materi-materi keislaman, seperti materi Fiqh, Akidah Akhlak, Al-qur'an Hadis serta materi-materi pengetahuan umum yang berguna untuk anak berhadapan dengan hukum $(\mathrm{ABH})$. Pembinaan ini, dirancang dengan jadwal yang tersusun rapi, dan dengan narasumber yang berasal dari berbagai pihak dan instansi yang ikut dalam pertemuan ini. Tujuan dari pembinaan ini untuk meningkatkan wawasan, pengetahuan, keterampilan, nilai dan sikap anak berhadapan dengan hukum $(\mathrm{ABH})$. Setelah terjadi peningkatan yang lebih baik, maka dapat digunakan ABH sebagai persyaratan untuk mengikuti program Bebas Bersyarat yang dikeluarkan oleh pihak Lapas Kelas II A Curup.

2. Pemberian Materi Keislaman

Pemberian materi Keislaman kepada Anak yang berhadapan dengan Hukum kelas II A Curup Kabupaten Rejang Lebong dengan menggunakan berbagai metode yang telah dikemukakan, seperti metode metode ceramah, diskusi, tanya jawab, praktek serta berbagai metode lainnya yang disesuaikan dengan materi yang akan diajarkan. Pemberian materi ini juga dengan menggunakan sarana prasarana seperti masjid, aula, serta pemanfaatan media Audio Visual. Pemberian materi keislaman ini juga bertujuan untuk meningkatkan wawasan, pengetahuan, keterampilan, sikap dan nilai (WPKNS) anak yang berhadapan dengan hukum (ABH) di Lapas Kelas II A Curup Kabupaten Rejang Lebong. Wawasan yang dimaksud disini wawasan keislaman, pengetahuan tentang materi keagamaan, sikap dalam bentuk akhlak yang baik kepada orang tua, teman, pegawai Lapas Kelas II A Curup, dan lingkungan sekitar. Keterampilan yang diharapakan berupa keterampilan dalam pelaksanaan ibadah, seperti keterampilan melaksanakan wudhu, tayamum, shalat lima waktu, dll.

Pemberian materi tidak hanya diajarkan langsung oleh para mentor, tetapi juga dilakukan dengan pemanfaatan media Speaker Rellay yang diberikan oleh peneliti kepada pihak Lapas untuk memutar materi-materi keislaman, seperti ceramah agama, ayat-ayat Al-Qur'an, lagu-lagu Islami. Penggunaan Speker Rellay membantu peneliti dalam memberikan materi keislaman langsung ke sel-sel tempat anak berhadapan dengan hukum (ABH) berada. Pemutaran materi keislaman ini dilakukan pada saat menjelang pelaksanaan shalat lima waktu dan setelah selesai pelaksanaan shalat lima waktu. 


\section{Pemberian Materi Umum}

Pemberian materi umum maksudnya pemberian materi selain materi keislaman, yaitu tentang pengetahuan-pengetahuan umum dasar seperti mata pelajaran, Matematika, Ilmu Pengetahuan Alam (IPA), Ilmu Pengetahuan Sosial dan Bahasa Indonesia. Setiap materi ditujukan dalam rangka meningkatkan wawasan, pengetahuan, keterampilan, nilai dan sikap yang perlu diketahui dan dimiliki oleh anak berhadapan dengan hukum $(\mathrm{ABH})$ Lapas Kelas II A Curup kabupaten Rejang Lebong. Pemberian materi umu di sini disesuaikan dengan tingkat pendidikan berdasarkan usia $\mathrm{ABH}$, dan kelas yang ditinggalkan pada saat masuk ke dalam LAPAS.

\section{Pemberian Keterampilan Softskill}

Pemberian keterampilan Softskill dilaksanakan dengan memberikan keterampilan membuat Pot Bunga untuk anak yang berhadapan dengan hukum $(\mathrm{ABH})$. Keterampilan ini diharapkan menjadi bekal untuk $\mathrm{ABH}$ dalam menjalani kehidupan setelah keluar dari LAPAS kelas II A Curup, dengan bekal keterampilan ini diharapkan $\mathrm{ABH}$ tidak mengulangi perbuatannya kembali di masa lalu yang menyebabkan mereka masuk ke dalam LAPAS.

5. Pemberian Pengetahuan dan Wawasan Kebangsaan

Pemberian materi pengetahuan dan wawasan kebangsaan kepada $\mathrm{ABH}$ Lapas Kelas II A Curup dilaksanakan peneliti bekerjasama dengan pihak kepolisian Rejang Lebong. Kegiatan ini dilaksanakan pada hari Kamis, tanggal 27 Juli 2018. Narasumber dari kegiatan ini adalah Bapak Nurdai, S.Pd Kasat Binmas Kepolisian Rejang Lebong. Kegiatan ini dilaksanakan dengan menjelaskan pentingnya Undang-Undang dan Pancasila sebagai dasar negara, pentingnya kesatuan NKRI, dan mencegah timbulnya konflik dan permaslahan yang timbul di masyarakat.

6. Pemberian Layanan Konseling

Pemberian layanan konseling kepada anak yang berhadapan dengan Hukum (ABH) Lapas kelas II A Curup Kabupaten Rejang Lebong dilaksanakan dengan tujuan mengemukakan permasalahan yang dihadapi oleh $\mathrm{ABH}$, serta mencarikan sebuah solusi pemecahan masalah $\mathrm{ABH}$ melalui kegiatan layanan konseling. Kegiatan ini dilaksanakan dengan bekerjasama dengan himpunan mahasiswa program studi (HMPS) Bimbingan Konseling IAIN Curup. Kegiatan ini dilaksanakan pada hari kamis, tanggal 01 November 2018. Kegiatan layanan konseling dilaksanakan dengan berkelompok dan layanan konseling individual.

7. Mengadakan Perlombaan Keislaman

Perlombaan Keislaman diadakan pada hari kamis, tanggal 22 November 2018. Kegitan perlombaan ini diadakan dalam rangka mengevaluasi program pembinaan dan berbagai kegiatan yang dilakukan kepada anak berhadapan 
dengan Hukum (ABH) Lapas Kelas II A Curup Kabupaten Rejang Lebong. Cabang perlombaan terdiri dari lomba adzan, lomba mengaji, lomba hapalan surah-surah pilihan dala Al-Qur'an. Kegiatan ini dilakukan agar anak-anak yang mendapatkan materi keagamaan selama ini dapat menerapkan apa yang telah didapatkan selama ini ke dalam kehidupan sehari-hari mereka. Sehingga ABHakan merasa bahwa kegiatan yang telah dilakukan selama ini tidak sia-sia saja.

\section{Penutup}

Tindakan yang dilakukan dalam penelitian ini dalam meningkatkan WPKNS ABH, yaitu pemberian bantuan sumbangan kepada LAPAS Kelas II A Curup, melakukan koordinasi dengan pihak LAPAS dan Stakeholder, pemberian materi keislaman kepada $\mathrm{ABH}$ kelas II A Curup, pemberian materi pendidikan umum,pemberian keterampilan Softskill,pemberian pengetahuan dan wawasan kebangsaan kepada ABH LAPAS Kelas II A Curup, pemberian layanan konseling kepada ABH LAPAS Kelas IIA Curup, mengadakan Perlombaan Keislaman

Hasil penelitian dan tindakan menunjukkan wawasan, pengetahuan, keterampilan, nilai dan sikap ABH di LAPAS kelas II A Curup, sebelum dan sesudah tindakan yaitu: wawasan $\mathrm{ABH}$ mengalami peningkatan sebesar 52,5\% dari skor total sebelum tindakan berjumlah $28(35 \%)$ meningkat menjadi total keseluruhan $75(87,5 \%)$ setelah tindakan. Pengetahuan ABH mengalami peningkatan sebesar $41,25 \%$, skor total keseluruhan sebelum dilaksanakan tindakan berjumlah $62(38,75 \%)$ meningkat menjadi $128(80 \%)$ setelah tindakan. Keterampilan $\mathrm{ABH}$ mengalami peningkat sebesar 52,5\% dari skor total berjumlah $28(35 \%)$ sebelum tindakan menjadi 75 (87,5\%) setelah dilaksanakan tindakan. Aspek nilai ABH mengalami peningkatan sebesar 58,75\% dari skor total awal berjumlah $26(32,5 \%)$ menjadi $73(91,25 \%)$ setelah dilaksanakan tindakan. Aspek sikap ABH mengalami peningkatan sebesar 43,75\% dari skor total berjumlah $35(43,75 \%)$ menjadi $75(87,5 \%)$ setelah dilaksanakan tindakan.

\section{Daftar Pustaka}

Aditia. D. K., \& Pujiyono. A. M. (2016). Analisis Yuridis Penjatuhan Sanksi Pidana terhadap anak yang Berkonflik dengan Hukum(Studi Kasus Putusan Pengadilan Negeri Tegal No. 32/Pid. Sus-ank/2014/ PN TGL). Diponegoro Law Journal. 5

Anam, Khiyarul. 2014. Meningkatkan Ketrampilan Membaca Nyaring Melalui Media Pias-pias kata pada Siswa Kelas I di MI Matholibul Huda Ruwit Wedung Demak Tahun Pelajaran 2014-2015,Skripsi. Fak, Ilmu Tarbiyah dan Keguruan, IAIN Walisongo. 
Aro, S., \& Sanur, Y. T. 2013. Sikap Pemuda Terhadap Budaya Daerah Jatilan Di Desa Rejomulyo Lampung Selatan.

Ardiyan, Rendi, “Pengertian Sikap”,Rendi_Ar@yahoo.com, tanggal 25 November 2018

Arsyad, Azhar. 2003. Media Pembelajaran. Jakarta: Raja Grafindo . 2015. Media Pembelajaran.Jakarta: Rajawali pers

Asnawir dan M. Basyiruddin Usman. 2002. Media Pelajaran. Jakarta: Ciputat Pers

Desi Susanti, dkk. 2014. Pengembangan Media Pembelajaran Video Drama Berbasis Audio Visual Mata Pelajaran IPS Terpadu. Pascasarjana Pendidikan IPS.

Djamil, M. Nasir. 2013. Anak Bukan Untuk di Hukum. Jakarta: Sinar Grafika

Erpan, Erik. 2016. Gambaran Keterampilan Pemasangan Infus pada Perawat Vakasional dan Perawat Profesional Rumah Sakit PKU Muhammaddiyah di Wilayah Yogyakart. Skripsi. Fak. Kedokteran, UMY

Fatah Syukur NC, 2005. Teknologi Pendidikan. Semarang: Rasail

Febry Hizba Ahshaina Suharto, d. ,. (n.d.). Interaksi didalam Keluarga dengan Anak Berhadapan dengan Hukum di Panti Sosial Masurdi Putra Bambu Apus Jakarta. Share Social Work Jurnal, Volume: 5 Nomor: 1, Hal. 3545.

Fitriani, I. 2014. Nilai-Nilai Pendidikan Islam dalam Novel "Bumi Cinta" Karya Habiburrahman El-Shirazy (Doctoral dissertation, UIN Sunan Ampel Surabaya).

Gay, L. 1983. Educational Research Competencies for Analysis \& Application (2nd Edition ed.). Ohio: A Bell \& Howell Company.

Gottman, John \& Joan DeClaire. 1997. Kiat-kiat Membesarkan Anak yang Memiliki Kecerdasan Emosional, terj. T. Hermaya. Jakarta: Gramedia Pustaka Utama, 1997

Hidayatpulo, Cara memdapatkan Wawasan yang Luas hidayatpulo@gmail.com, tanggal 25 November 2018

http://dosensosiologi.com/macam-macam-nilai diakses tanggal 25 November 2018

http://kerajaan-semut.blogspot.com/2010/04/tinjauan-dan-

pengertianpengetahuan-dan.html di akses tanggal 25 November 2018

https://www.matabaraja.com/2017/09/keterampilan.html, diakses pada tanggal 25 November 2018 
https://www.matabaraja.com/2017/09/keterampilan.html, diakses pada tanggal 25 November 2018

Indahyani,Fauziyah. 2015. Studi Deskriptif Kuantitatif Pengetahuan Guru Sekolah Dasar Tentang Bullying di Kecamatan Sokaraja Kabupaten Banyumas Skripsi, Fak. Psikologi UMP.

Jatmiko Sidi, Mukminan. Juni 2016. Penggunaan Media Audiovisual untuk Meningkatkan Hasil belajar IPS di SMP. Jurnal Ilmu-Ilmu Sosia, Volume 15. No.1, Hal. 53-72.

Keputusan Presiden Nomor 36 Tahun 1990 Tentang Konvensi Hak Anak.

Khairunissa, Nurul. Wawasan dan Pengetahuan, Nurul Khairunissa@yahoo.com, tanggal 25 November 2018

Kurniawan Rasmen, Anak Yang Berhadapan dengan Hukum diakses pukul 15.00 WIB 15 Oktober 2018

Meilyana Megasari,Nyoman Dewa Rai Asmara Putra. 2017. Tinjauan Yuridis Terkait Faktor dan Upaya Menanggulangi Kenakalan Anak yang Berkonflik dengan Hukum. Universitas Udayana.

Murfiah, U. April 2017. Model Pembelajaran Terpadu di Sekolah Dasar. Jurnal Pesona Dasar, Vol. 1 No. 5, hal. 57 - 69.

Puspita, Wulan, Macam-macam Keterampilan, Wulanpuspita@gmail.com, tanggal 25 November 2018.

Purwanto, Heri. 1998 Pengantar Perilaku Manusia Untuk Keperawatan. Jakarta: EGC

Rahmawati, Fitria, 2016, Hubungan Pengetahuan Ibu, Pola Pemberian Makan, dan Pendapatan Keluarga terhadap Status Gizi Balita di Desa Pajerukan Kecamatan Kalibagor, Skripsi, Fak. Ilmu Kesehatan UMP

Rinanto, A. 1982. Peranan Media Audiovisual dalam Pendidikan. Yogyakarta: Kanisius.

Ruman, Y. S. 2016. Keteraturan Sosial, Norma dan Hukum: Sebuah Penjelasan Sosiologis. PRIORIS, 2(2), 106-116.

Sadirman, Arif. 1996. Media Pembelajaran. Jakarta: RaiawalI Pers

Soetodjo, W. 2006. Hukum Pidana Anak. Bandung: PT. Refika Aditama.

Staf MRPK, Arti Kata Wawasan Makna Pengertian Dan Definisi Dari Wawasan, ddmrpk@gmail.com, 15 November 2018.

Sudjana, Nana. 1978. Media Pengajaran. Surabaya:Pustaka Dua, 1978 
1989. Teknologi Pengajaran. Bandung: Sinar Baru

Suprijanto. 2005. Pendidikan Orang Dewasa. Jakarta: Bumi Aksara

Suryoputro, A., Ford, N. J., \& Shaluhiyah, Z. 2006. Faktor-faktor yang Mempengaruhi Perilaku Seksual Remaja di Jawa Tengah: Implikasinya terhadap Kebijakan dan Layanan Kesehatan Seksual dan Reproduksi.Makara Kesehatan, 10(1), 29-40.

Taufik, Imam. 2013. Penerapan Media Audio Visual Dalam Meningkatkan Presentasi Belajar Bahasa Arab. Yogyakarta : UIN Sunan Kali Jaga

Tim Pengembang , P. G. S. D 1997. Pembelajaran terpadu d-ii dan s-2 pendidikan dasar. Depatermen Pendidikan dan Kebudayaan

Kitab Undang-undang Hukum Pidana (KUHP).

Undang-undang Nomor 8 Tahun 1981 Tentang Kitab Undang-undang Hukum Acara Pidana (KUHAP).

Undang-undang Nomor 3 Tahun 1997 Tentang Pengadilan Anak.

Undang-undang Nomor 39 Tahun 1999 Tentang Hak Asasi Manusia.

Undang-undang Nomor 11 Tahun 2012 Tentang Sistem Peradilan Anak.

Undang-undang Nomor 35 Tahun 2014 Tentang Perubahan atas Undangundang Nomor 23 Tahun 2002 Tentang Perlindungan Anak.

Undang-Undang Sistem Pendidikan Nasional Nomor 20 Tahun 2003.

Wati. V. A. 2010. Pengembangan Multimedia Pembelajaran untuk Mata Kuliah Pembelajaran Terpadu. Jurnal Penelitian Ilmu Pendidikan. Yogyakarta: FIP Universitas Negeri Yogyakarta

Widodo, S. Januari 2017. Diversi sebagai Bentuk Perlindungan Hak Asasi Anak yang Berhadapan dengan Hukum(Studi di Pengadilan Negeri Purwokerto). Jurnal Kosmik Hukum, Vol. 17 No. 1. 